\title{
Effects of 3-nitrooxypropanol on methane emission, digestion, and energy and nitrogen balance of lactating dairy cows
}

\author{
C. K. Reynolds, ${ }^{* 1}$ D. J. Humphries, ${ }^{*}$ P. Kirton, ${ }^{*}$ M. Kindermann, $†$ S. Duval, $\ddagger$ and W. Steinberg ${ }^{1}$ \\ *School of Agriculture, Policy and Development, University of Reading, PO Box 237, Earley Gate, Reading, RG6 6AR, United Kingdom \\ †DSM Nutritional Products Ltd., PO Box 2676, CH-4002 Basel, Switzerland \\ fDSM Nutritional Products, Research Centre for Animal Nutrition and Health, BP 170, F-68305 Saint-Louis Cedex, France
}

\section{ABSTRACT}

The objective was to measure effects of 3-nitrooxypropanol $(3 \mathrm{NP})$ on methane production of lactating dairy cows and any associated changes in digestion and energy and N metabolism. Six Holstein-Friesian dairy cows in mid-lactation were fed twice daily a total mixed ration with maize silage as the primary forage source. Cows received 1 of 3 treatments using an experimental design based on two $3 \times 3$ Latin squares with 5 -wk periods. Treatments were a control placebo or 500 or $2,500 \mathrm{mg} / \mathrm{d}$ of $3 \mathrm{NP}$ delivered directly into the rumen, via the rumen fistula, in equal doses before each feeding. Measurements of methane production and energy and $\mathrm{N}$ balance were obtained during wk 5 of each period using respiration calorimeters and digestion trials. Measurements of rumen $\mathrm{pH}(48 \mathrm{~h})$ and postprandial volatile fatty acid and ammonia concentrations were made at the end of wk 4. Daily methane production was reduced by $3 \mathrm{NP}$, but the effects were not dose dependent (reductions of 6.6 and $9.8 \%$ for 500 and $2,500 \mathrm{mg} / \mathrm{d}$, respectively). Dosing $3 \mathrm{NP}$ had a transitory inhibitory effect on methane production, which may have been due to the product leaving the rumen in liquid outflow or through absorption or metabolism. Changes in rumen concentrations of volatile fatty acids indicated that the pattern of rumen fermentation was affected by both doses of the product, with a decrease in acetate:propionate ratio observed, but that acetate production was inhibited by the higher dose. Dry matter, organic matter, acid detergent fiber, N, and energy digestibility were reduced at the higher dose of the product. The decrease in digestible energy supply was not completely countered by the decrease in methane excretion such that metabolizable energy supply, metabolizable energy concentration of the diet, and net energy balance (milk plus tissue energy) were reduced by the highest dose of 3NP. Similarly, the decrease in

Received August 21, 2013.

Accepted January 10, 2014.

${ }^{1}$ Corresponding author: c.k.reynolds@reading.ac.uk
$\mathrm{N}$ digestibility at the higher dose of the product was associated with a decrease in body $\mathrm{N}$ balance that was not observed for the lower dose. Milk yield and milk fat concentration and fatty acid composition were not affected but milk protein concentration was greater for the higher dose of 3NP. Twice-daily rumen dosing of $3 \mathrm{NP}$ reduced methane production by lactating dairy cows, but the dose of $2,500 \mathrm{mg} / \mathrm{d}$ reduced rumen acetate concentration, diet digestibility, and energy supply. Further research is warranted to determine the optimal dose and delivery method of the product.

Key words: 3-nitrooxypropanol, methane, digestion, rumen, dairy cow

\section{INTRODUCTION}

In recent years, a massive global research effort has explored potential nutritional, genetic, and management options for reducing methane emissions from ruminants. Several potential approaches have shown promise (e.g., Blaxter and Czerkawski, 1966; Mills et al., 2001; Beauchemin et al., 2008; McAllister and Newbold, 2008). These include changes in carbohydrate amount and type (e.g., starch or sugar vs. fiber), supplemental fats (through replacement of fermentable substrate and inhibitory effects on methanogenesis), feeding precursors of propionate such as fumaric or malic acid, or feeding bioactive compounds such as ionophores or plant components. Examples of plant bioactive components that are purported to inhibit methanogenesis include compounds from garlic, tannins, or saponins (Beauchemin et al., 2008; McAllister and Newbold, 2008). In addition, hydrogen acceptors such as nitrate or sulfate have been successful in reducing methane production in sheep and dairy cows (Bozic et al., 2009; van Zijderveld, 2011) and inhibitory effects of chloral hydrates on methane production have been observed both in vitro and in vivo (Trei et al., 1972; Clapperton, 1974; Goel et al., 2009; Abecia et al., 2012). In regard to bioactive compounds, supplements that are effective at reducing methane production in sheep have, in some cases, been found to be ineffective 
in lactating dairy cows (McCourt et al., 2008; Foley et al., 2009), which may be due to differences in rumen ecology and dynamics.

In addition to specific plant bioactive compounds, there is now interest in the potential development of synthetic compounds as specific inhibitors of methanogenesis (Soliva et al., 2011). In this regard, in silico screening (Halgren et al., 2004) has identified several compounds as potential inhibitors of methyl-coenzyme $\mathrm{M}$ reductase, the final step in the reduction of $\mathrm{CO}_{2}$ to $\mathrm{CH}_{4}$ by methanogenic archaea (Duval and Kindermann, 2012). Two of these compounds, ethyl-3-nitrooxy propionate and 3-nitrooxypropanol (3NP), have recently been shown to be effective at inhibiting methane production in vitro and when fed to sheep for $30 \mathrm{~d}$ (Martínez-Fernández et al., 2014). The objective of the present study was to determine the effects of 2 doses of $3 \mathrm{NP}$ on methane production by lactating dairy cows and any associated effects on diet digestion and energy and $\mathrm{N}$ metabolism. Our hypothesis was that $3 \mathrm{NP}$ would reduce methane production in lactating dairy cows.

\section{MATERIALS AND METHODS}

\section{Animals and Diet}

Six second-parity Holstein-Friesian cows averaging $33.4 \mathrm{~kg} / \mathrm{d}$ milk yield and 200 DIM at the start of the study were used. Three of the cows were pregnant (92, 97, and $140 \mathrm{~d}$ ) at the start of the study. An additional cow was confirmed pregnant at the end of the study (55 d). Cows had rumen fistulas established during their first lactation with cannulas (Bar Diamond, Parma, ID) inserted. All procedures were licensed and monitored by the UK Home Office under the Animal Science (1986) Procedures Act. Throughout the study, cows were fed a TMR (Table 1) for ad libitum DMI (5\% refusals). Animals were fed twice daily, receiving twothirds of their daily allocation in the morning and the remaining one-third in the afternoon. Refused food was removed and weighed daily before the morning feeding. Cows were milked twice daily at approximately 0630 and $1630 \mathrm{~h}$. When not restrained for measurements, cows were housed in a cubicle yard with rubber chipfilled mattresses and wood shavings as additional bedding and were milked in a herringbone parlor. While in the cubicle yard, cows were fed individually using an electronic identification controlled pneumatic feed barrier (Insentec, Marknesse, the Netherlands), and drinking water was constantly available from troughs. While restrained in tiestalls or chambers for measurements described below, cows had continuous access to drinking water through drinking bowls and were milked using a pipeline system.
Table 1. Composition of the $\mathrm{TMR}^{1}$ fed

\begin{tabular}{lc}
\hline Ingredient & $\mathrm{g} / \mathrm{kg}$ of DM \\
\hline Grass silage $^{2}$ & 60 \\
Maize silage $^{3}$ & 420 \\
Chopped straw & 32 \\
Ground wheat & 110 \\
Ground barley & 95 \\
Soybean meal & 118 \\
Palm kernel (expeller) & 54 \\
Distillers dried grains & 45 \\
Sugar beet pulp & 40 \\
Megalac & 6 \\
Urea & 5 \\
Minerals and vitamins & 15 \\
\hline
\end{tabular}

${ }^{1}$ Average $\mathrm{OM}, \mathrm{CP}, \mathrm{NDF}, \mathrm{ADF}$, and starch concentrations (g/kg of DM) of $925,182,398,278$, and 166 , respectively.

${ }^{2}$ Average CP, NDF, and ADF concentrations (g/kg of DM) of 159 , 564 , and 362 , respectively.

${ }^{3}$ Average CP, NDF, ADF, and starch concentrations ( $/ \mathrm{kg}$ of $\mathrm{DM}$ ) of $78,439,242$, and 291, respectively.

${ }^{4}$ Volac International Ltd. (Orwell, UK).

\section{Experimental Design and Treatments}

The experimental design was based on 3 treatments and 2 balanced $3 \times 3$ Latin squares with 5 -wk periods. Treatments were a control and 2 doses (500 and 2,500 $\mathrm{mg} / \mathrm{d}$ ) of $3 \mathrm{NP}$. The $3 \mathrm{NP}$ was formulated at $50 \%$ on silica oxide $\left(\mathrm{SiO}_{2}\right)$ and was kept in a sealed container under refrigeration $\left(2\right.$ to $\left.4^{\circ} \mathrm{C}\right)$ before weighing for administration. Doses were then weighed and wrapped in a single facial tissue and kept in a sealed container before administration through the rumen fistula approximately $10 \mathrm{~cm}$ below the surface of the rumen contents. The control treatment was the administration of a single tissue through the rumen fistula.

\section{Measurements}

Milk yield was recorded daily using milk meters throughout the 35 -d period. Cows were weighed at the beginning of the study and at the end of each period.

\section{Rumen Sampling}

During wk 4 of each period (d 24 to 28), animals were transferred to individual tiestalls with rubber mats and wood chip bedding to acclimatize cows to restraint by head yoke and obtain rumen measurements. Rumen fluid samples were taken on d 27, just before and at $0.5,1.0,1.5,2.0$, and $4.0 \mathrm{~h}$ after both the a.m. and p.m. feedings. Rumen fluid samples $(100 \mathrm{~mL})$ were collected from the ventral sac via aspiration through a coarse filtered tube inserted vertically approximately $40 \mathrm{~cm}$ into the rumen mat directly below the rumen fistula. The sample was mixed thoroughly and $\mathrm{pH}$ measured 
immediately. Subsamples were then stored frozen at $-20^{\circ} \mathrm{C}$ until analysis of VFA and ethanol (Aikman et al., 2011) and ammonia concentrations (Sutton et al., 2003) by GLC and colorimetric procedures, respectively; . Samples for ammonia analysis were acidified to $\mathrm{pH} 2.0$ by addition of concentrated sulfuric acid. In addition, 24-h mid-rumen $\mathrm{pH}$ measurements were conducted on d 26 and 27. A pH electrode was placed within the rumen via the cannula, and connected to a $\mathrm{pH} 340 \mathrm{i}$ data recorder (Wissenschaftlich-Technische Werkstätten GmbH, Weilheim, Germany). The connection between the cannula and the end of the $\mathrm{pH}$ electrode was 30 $\mathrm{cm}$, and the electrode was weighted to ensure that it sank through the rumen mat rather than lying on the surface. The equipment was calibrated before each use. The electrode was placed into the rumen immediately before the morning feeding and removed $48 \mathrm{~h}$ later. Rumen $\mathrm{pH}$ was recorded every $15 \mathrm{~min}$. These rumen $\mathrm{pH}$ measurements were used to calculate the length of time within each 24-h measurement period when $\mathrm{pH}$ was below $\mathrm{pH} 5.7,6.0$, or 6.5 .

\section{Respiration Chamber Measurements}

For the last $5 \mathrm{~d}$ of each period (d 30 to 34 ), cows were transferred to respiration chambers, where they were restrained by head yoke, and four 24-h measurements of methane production and respiratory exchange $\left(\mathrm{CO}_{2}\right.$ production and $\mathrm{O}_{2}$ consumption) were obtained (Cammell et al., 2000; Reynolds et al., 2001). While cows were in the chambers, all feces and urine excreted was collected, weighed, and sampled for determination of diet digestion and energy and $\mathrm{N}$ balance as described by Reynolds et al. (2001) except that urine and feces collection was modified so that urine collection cups were not affixed to the cows using glue. Urine and feces were directed to a urine collection container via a common collection chute attached to the cow using elastic bands attached to a padded surcingle. The excreta were directed onto a nylon screen $(2 \mathrm{~mm})$ that retained the feces and allowed the urine to pass through into the collection container. Feces were removed from the screen and transferred into a separate container at regular intervals (5 times/d). A secondary silk screen underneath the nylon screen retained any small particles of feces that passed through the primary screen to minimize contamination of urine with insoluble fecal particles. These small particles were weighed as feces but not included in the feces sampled for analysis. Each day, the feces collected were thoroughly mixed and a $5 \%$ subsample was frozen in a sealed container. At the end of the collection period, fecal samples were thawed and thoroughly mixed. Subsamples were analyzed for N concentration or stored at $-20^{\circ} \mathrm{C}$ for subsequent analysis of energy (Reynolds et al., 2001). Further subsamples were analyzed for $\mathrm{DM}$ concentration $\left(5 \mathrm{~d}\right.$ at $\left.65^{\circ} \mathrm{C}\right)$, with the dried fecal samples stored at room temperature before analysis of ash, starch, NDF, and ADF concentrations (Kliem et al., 2013). The $\mathrm{pH}$ of urine accumulating in the collection tray was maintained $<2$ by the addition of sufficient $10 \mathrm{~N}$ sulfuric acid (1.2 L) to the tray before commencing collection. The total urine collected each day was weighed and mixed, and a subsample of $5 \%$ of the total weight was removed and frozen $\left(-20^{\circ} \mathrm{C}\right)$ in a sealed plastic bottle. At the end of the 5-d collection period, the subsamples were thawed, bulked, and divided into 2 aliquots that were centrifuged to remove any fecal particle contamination; the supernatant was stored at $-20^{\circ} \mathrm{C}$ until analyzed for energy and $\mathrm{N}$ concentration (Reynolds et al., 2001). The procedures used sought to minimize cross contamination of feces and urine, but some cross contamination was unavoidable. Cross contamination of soluble components of feces and urine could affect volatile $\mathrm{N}$ losses and measurements of $\mathrm{N}$ excretion in urine and feces.

\section{Milk Samples}

For the last $5 \mathrm{~d}$ of each period, milk was sampled (25 $\mathrm{mL})$ at each milking, treated with preservative $(1 \mathrm{mg} /$ $\mathrm{mL}$ potassium dichromate), and stored at $4^{\circ} \mathrm{C}$ before infrared analysis for fat, protein, lactose, casein, and urea concentrations and SCC (National Milk Laboratories, Wolverhampton, UK). Milk composition was used to calculate 3.5\% FCM yield (Gaines, 1928) and milk energy yield (Reynolds et al., 2001). On d 34 of each period, 2 sequential milk samples (a.m. and p.m.) were frozen for analysis of FA composition as described by Kliem et al. (2013).

\section{Diet Samples}

Samples of the TMR were taken on a daily basis and subjected to immediate DM analysis $\left(100^{\circ} \mathrm{C}\right.$ for $23 \mathrm{~h}$ ) for estimation of DMI. During the last week of each period, representative samples of the TMR and the individual TMR components were taken daily, and each aliquot was added to a sealed plastic bag stored at $-20^{\circ} \mathrm{C}$ to create a bulked sample. At the end of the period, these bulked samples were thawed, mixed, split into subsamples, and stored at $-20^{\circ} \mathrm{C}$ until required for analysis. A representative sample of refused feed was also taken during digestion trials. These samples were analyzed for DM content $\left(100^{\circ} \mathrm{C}\right.$ for $\left.23 \mathrm{~h}\right)$, and subsampled, stored, and bulked as described for diet samples. Samples of feeds and refusals were analyzed for energy and N concentration (Reynolds et al., 2001) and for ash, starch, NDF, and ADF concentrations 
using chemical analyses as described by Kliem et al. (2013).

\section{Statistical Analyses}

Results averaged for each cow and sampling period (18 observations) were analyzed statistically using the Mixed Models procedures of SAS (SAS Institute Inc., Cary, NC), testing fixed effects of square, period, and treatment and the random effects of cow within square. Period was considered as a repeated effect using the covariance structure (autoregressive, heterogeneous autoregressive, compound symmetry, heterogeneous compound symmetry, or unstructured) giving the best fit (Tempelman, 2004). In initial analysis of the data, the effect of treatment $\times$ period interaction was included in the model, but this interaction did not approach significance and was removed from the model used for the results presented. In addition, least squares means for each dose of $3 \mathrm{NP}$ were compared with the control mean using Dunnett comparisons. For rumen fluid measurements at specific sampling times, time of sampling relative to feeding (time) and feeding time (a.m. or p.m.) were included as fixed effects in the model along with their 2- and 3-way interactions, with time relative to feeding as a repeated effect. Because of the limited number of observations, treatment effects were considered significant at $P<0.10$.

\section{RESULTS}

\section{Animal Health}

Overall, few health problems were noted during the study. No cases of mastitis and 1 case of mild lameness were reported. One cow aborted twins in early gestation in the first week of period 3 but was not measurably affected in terms of general health and production.

\section{Milk Yield and Composition}

During measurements of respiratory exchange and digestion, 3NP had no significant effect on milk yield, FCM yield, or milk energy yield (Table 2). Numerically, milk yield was reduced by $2.9 \mathrm{~kg} / \mathrm{d}$ on the higher dose of $3 \mathrm{NP}(P=0.19)$, which resulted in an increase in milk protein and casein concentrations $(P<0.01)$, as milk protein yield was not affected. The product had no effect on milk fat or lactose concentrations or yields or on milk urea concentration. Milk energy and FCM production were also not affected. In addition, 3NP did not affect concentrations of any of the FA measured in milk fat (Table 3).

\section{Intake and Digestion of Diet Components and Nitrogen Balance}

Treatment with 3NP had no effect on DMI (Table 4 ), but fecal DM excretion was increased by both doses of $3 \mathrm{NP}$ ( $P<0.07$ and $P<0.09$, respectively), and DM and $\mathrm{OM}$ digestibility $(\mathrm{g} / \mathrm{kg})$ were reduced by the 2,500 $\mathrm{mg} / \mathrm{d}$ dose $(P<0.08$ and $P<0.06$, respectively). Fecal NDF excretion was increased by both doses of $3 \mathrm{NP}(P$ $<0.09$ and $P<0.05$ for 500 and $2,500 \mathrm{mg} / \mathrm{d}$, respectively), whereas NDF digestion was reduced by the low dose $(P<0.10)$. Fecal ADF excretion was increased by both 500 and $2,500 \mathrm{mg} / \mathrm{d}$ doses $(P<0.05$ and $P<$ 0.06 , respectively), whereas digestibility of ADF was decreased by both doses $(P<0.08)$. Fecal excretion and digestibility of $\mathrm{N}$ (Table 5$)$ were increased $(P<$ $0.01)$ and decreased $(P<0.08)$, respectively, by the $2,500 \mathrm{mg} / \mathrm{d}$ dose, causing a decrease in body $\mathrm{N}$ balance $(P<0.10)$. Milk $\mathrm{N}$ excretion as a percentage of intake $\mathrm{N}$ was also reduced $(P<0.03)$ by the higher dose.

\section{Rumen $\mathrm{pH}$}

On average, manual measurements of $\mathrm{pH}$ at specific time points after feeding $(\mathrm{n}=216)$ were comparable to average measurements of rumen $\mathrm{pH}$ obtained using continuous electronic recording over successive 24-h periods $(\mathrm{n}=18$; Table 6$)$. When time of sampling was accounted for in the statistical analysis of manual measurements (Figure 1, Table 6), rumen $\mathrm{pH}$ was affected by both time of sampling and treatment $(P<0.001)$. However, the effect of treatment differed with the dose used. The $500 \mathrm{mg} / \mathrm{d}$ dose reduced average rumen $\mathrm{pH}(P$ $<0.03)$, whereas the $2,500 \mathrm{mg} / \mathrm{d}$ dose increased average rumen $\mathrm{pH}(P<0.10)$ when manual measurements were compared. The minimum $\mathrm{pH}$ recorded was lower for the $500 \mathrm{mg} / \mathrm{d}$ treatment $(P<0.06)$ and higher for the $2,500 \mathrm{mg} / \mathrm{d}$ dose $(P<0.02)$. In addition, less variation (smaller SD) in rumen $\mathrm{pH}$ was observed for the 2,500 $\mathrm{mg} / \mathrm{d}$ dose $(P<0.04)$.

\section{Rumen VFA and Ammonia Concentrations}

Concentrations of all VFA measured, except isobutyrate, isovalerate, and ethanol (Table 7), were greater $(P<0.001)$ after the afternoon feeding than after the morning feeding, and generally increased after feeding (Figure 2 shows patterns observed for total VFA). Acetate concentration was decreased by both doses $(P$ $<0.008$ and $P<0.001$ for 500 and $2,500 \mathrm{mg} / \mathrm{d}$, respectively), and the postprandial increases observed for the control treatment were reduced or did not occur when the product was fed (data not shown; time $\times$ treatment 
Table 2. Effects of 3-nitrooxypropanol on milk yield and composition and BW in dairy cows before and during respiration chamber measurements

\begin{tabular}{|c|c|c|c|c|c|c|c|}
\hline \multirow[b]{2}{*}{ Item } & \multicolumn{3}{|c|}{ Dose, mg/d } & \multirow[b]{2}{*}{ SEM } & \multicolumn{3}{|c|}{$P<1$} \\
\hline & 0 & 500 & 2,500 & & Trt & 0 vs. 500 & $\begin{array}{l}0 \text { vs. } \\
2,500\end{array}$ \\
\hline \multicolumn{8}{|c|}{ During rumen measurements (wk 4) } \\
\hline $\mathrm{DMI}, \mathrm{kg} / \mathrm{d}$ & 20.4 & 20.3 & 20.1 & 0.6 & 0.85 & 0.86 & 0.59 \\
\hline Milk yield, kg/d & 30.9 & 30.0 & 29.1 & 3.6 & 0.62 & 0.65 & 0.35 \\
\hline FCM yield, kg/d & 30.8 & 29.5 & 29.2 & 2.9 & 0.49 & 0.38 & 0.27 \\
\hline \multicolumn{8}{|c|}{ During respiration measurements (wk 5) } \\
\hline Milk yield kg/d & 28.7 & 27.6 & 25.8 & 3.2 & 0.38 & 0.61 & 0.19 \\
\hline FCM yield, kg/d & 28.5 & 27.1 & 26.4 & 2.7 & 0.42 & 0.41 & 0.21 \\
\hline Milk energy, MJ/d & 85.0 & 81.3 & 79.5 & 7.9 & 0.48 & 0.43 & 0.26 \\
\hline \multicolumn{8}{|l|}{ Milk composition } \\
\hline Fat, $\mathrm{g} / \mathrm{kg}$ & 40.2 & 40.0 & 41.4 & 1.8 & 0.28 & 0.82 & 0.21 \\
\hline Protein, $\mathrm{g} / \mathrm{kg}$ & 31.9 & 32.5 & 33.5 & 0.8 & 0.02 & 0.18 & $<0.01$ \\
\hline Casein, $\mathrm{g} / \mathrm{kg}$ & 23.0 & 23.4 & 24.4 & 0.6 & 0.02 & 0.26 & $<0.01$ \\
\hline Lactose, $\mathrm{g} / \mathrm{kg}$ & 42.6 & 42.7 & 43.1 & 0.7 & 0.74 & 0.92 & 0.48 \\
\hline Urea, mg/dL & 37.2 & 35.2 & 39.2 & 0.8 & 0.07 & 0.18 & 0.19 \\
\hline \multicolumn{8}{|l|}{ Milk yield } \\
\hline Fat, $\mathrm{g} / \mathrm{d}$ & 1,091 & 1,082 & 1,099 & 119 & 0.99 & 0.93 & 0.94 \\
\hline Protein, g/d & 875 & 877 & 888 & 106 & 0.98 & 0.98 & 0.88 \\
\hline Casein, g/d & 632 & 630 & 645 & 75 & 0.97 & 0.98 & 0.84 \\
\hline Lactose, $\mathrm{g} / \mathrm{d}$ & 1,183 & 1,165 & 1,180 & 157 & 0.99 & 0.89 & 0.99 \\
\hline $\mathrm{BW}, \mathrm{kg}$ & 674 & 669 & 673 & 35 & 0.90 & 0.68 & 0.96 \\
\hline Number of animals & 6 & 6 & 6 & & & & \\
\hline
\end{tabular}

${ }^{1}$ Probability for the effect of treatment (Trt), the difference between control and $500 \mathrm{mg} / \mathrm{d}$ means $(0$ vs. 500$)$, or the difference between control and $2,500 \mathrm{mg} / \mathrm{d}$ means ( 0 vs. 2,500).

interaction, $P<0.02)$. Propionate and n-valerate concentrations increased when the $500 \mathrm{mg} / \mathrm{d}$ dose was administered $(P<0.001$ and $P<0.02$, respectively $)$, but were not affected by the higher dose $(P=0.35$ and $P$ $=0.22$, respectively $)$. In contrast, both n-butyrate $(P<$ $0.002)$ and isobutyrate $(P<0.02)$ were increased by the high dose, but neither of these VFA concentrations was affected by the low dose (Table 7). Concentrations of isovalerate was decreased by the high dose $(P<0.007)$ but not affected by the low dose, whereas concentrations of caproate were decreased by the low dose $(P$ $<0.002)$ and increased by the high dose $(P<0.001)$. Total VFA concentrations were not affected by the low dose $(P=0.58)$, but were decreased $(P<0.01)$ by the high dose and increased after feeding to a greater extent for the control treatment (time $\times$ treatment interaction, $P<0.07$; Figure 2). Ethanol concentration was not affected by the low dose, but increased $(P<$ $0.01)$ by the high dose. Acetate:propionate and acetate + n-butyrate:propionate ratios were decreased by both doses $(P<0.008$ or less; Table 7$)$.

\section{Methane Production}

Methane production (L/d) and methane yield (L/ $\mathrm{kg}$ of DMI) were significantly reduced by the product (Table 8). Methane production was $93(P<0.03)$ and $90 \%(P<0.005)$ of control values for the 500 and 2,500 $\mathrm{mg} / \mathrm{d}$ doses, respectively. In regard to methane yield, the corresponding values were $96(P<0.02)$ and $93 \%$ $(P<0.004)$ of control methane yield, respectively, for the low and high doses of 3NP. Methane production per unit milk yield was not affected by either dose $(P$ $>0.14$ ), as a numerical reduction in milk yield occurred when cows were dosed with 3NP. Measurements of methane production obtained at 4-min intervals over the course of daily measurements showed that dosing $3 \mathrm{NP}$ into the rumen at feeding had transitory inhibitory effects on methane emission (Figure 3; hourly averages). This inhibitory effect was more pronounced for the $2,500 \mathrm{mg} / \mathrm{d}$ dose but, in most cases, only lasted for 2 to $3 \mathrm{~h}$. Methane production rate remained lower throughout most of the day (Figure 3), suggesting that the product effects are not entirely transitory but that residual effects were maintained throughout the day.

\section{Energy Balance}

Total intake of energy was not affected by treatment (Table 9), but the amount of energy digested was reduced by the higher dose of 3NP $(P<0.06)$. Treatment had no effect on urine energy excretion $(P>0.36)$. The decrease in methane energy loss observed was less than the decrease in digested energy; thus, ME supply $(P<$ $0.08)$ and therefore diet ME concentration $(P<0.09)$ were lower when $3 \mathrm{NP}$ was fed at $2,500 \mathrm{mg} / \mathrm{d}$. With the 
REYNOLDS ET AL.

Table 3. Effects of 3-nitrooxypropanol on milk FA concentrations (g/100 g of total FA) of dairy cows

\begin{tabular}{|c|c|c|c|c|c|c|c|}
\hline \multirow[b]{2}{*}{ Item } & \multicolumn{3}{|c|}{ Dose, mg/d } & \multirow[b]{2}{*}{ SEM } & \multicolumn{3}{|c|}{$P<{ }^{1}$} \\
\hline & 0 & 500 & 2,500 & & Trt & 0 vs. 500 & 0 vs. 2,500 \\
\hline 4:0 & 2.48 & 2.56 & 2.51 & 0.054 & 0.32 & 0.15 & 0.58 \\
\hline $5: 0$ & 0.02 & 0.03 & 0.02 & 0.005 & 0.24 & 0.10 & 0.37 \\
\hline $6: 0$ & 1.53 & 1.58 & 1.57 & 0.053 & 0.58 & 0.35 & 0.42 \\
\hline $7: 0$ & 0.01 & 0.01 & 0.02 & 0.005 & 0.38 & 0.58 & 0.41 \\
\hline $8: 0$ & 0.90 & 0.94 & 0.91 & 0.048 & 0.34 & 0.16 & 0.59 \\
\hline 9:0 & 0.01 & 0.02 & 0.02 & 0.004 & 0.19 & 0.12 & 0.11 \\
\hline 10:0 & 2.00 & 2.14 & 2.01 & 0.142 & 0.24 & 0.14 & 0.94 \\
\hline 10:1 cis-9 & 0.23 & 0.23 & 0.24 & 0.019 & 0.40 & 0.90 & 0.23 \\
\hline $11: 0$ & 0.03 & 0.04 & 0.04 & 0.006 & 0.72 & 0.66 & 0.44 \\
\hline $12: 0$ & 2.75 & 2.85 & 2.77 & 0.169 & 0.59 & 0.36 & 0.90 \\
\hline $12: 1$ cis -9 & 0.07 & 0.07 & 0.07 & 0.007 & 0.93 & 1.00 & 0.75 \\
\hline $13: 0$ & 0.06 & 0.06 & 0.06 & 0.005 & 0.92 & 0.91 & 0.79 \\
\hline 14:0 iso & 0.08 & 0.10 & 0.08 & 0.015 & 0.66 & 0.51 & 0.85 \\
\hline $14: 0$ & 9.90 & 10.10 & 9.90 & 0.401 & 0.59 & 0.38 & 0.99 \\
\hline 14:1 trans -9 & 0.21 & 0.23 & 0.21 & 0.008 & 0.55 & 0.36 & 0.98 \\
\hline 14:1 cis-9 & 0.97 & 0.91 & 1.01 & 0.080 & 0.31 & 0.35 & 0.54 \\
\hline $15: 0$ & 0.73 & 0.78 & 0.77 & 0.030 & 0.39 & 0.21 & 0.28 \\
\hline 15:0 anteiso & 0.37 & 0.42 & 0.40 & 0.017 & 0.28 & 0.14 & 0.33 \\
\hline 16:0 iso & 0.23 & 0.27 & 0.22 & 0.024 & 0.52 & 0.35 & 0.97 \\
\hline $16: 0$ & 31.20 & 30.76 & 31.22 & 0.275 & 0.12 & 0.12 & 0.93 \\
\hline $16: 1$ cis $-9^{2}$ & 1.45 & 1.33 & 1.52 & 0.059 & 0.11 & 0.15 & 0.38 \\
\hline $16: 1$ cis-11 & 0.42 & 0.47 & 0.43 & 0.019 & 0.07 & 0.03 & 0.54 \\
\hline $16: 1$ cis-13 & 0.10 & 0.10 & 0.11 & 0.010 & 0.97 & 0.94 & 0.82 \\
\hline $16: 1$ trans $-6-7$ & 0.06 & 0.06 & 0.06 & 0.006 & 0.96 & 0.98 & 0.82 \\
\hline $16: 1$ trans $-9^{3}$ & 0.29 & 0.29 & 0.29 & 0.016 & 0.94 & 0.79 & 0.75 \\
\hline $16: 1$ trans $-11-13$ & 0.21 & 0.21 & 0.21 & 0.012 & 0.94 & 0.73 & 0.86 \\
\hline $17: 0$ & 0.39 & 0.40 & 0.39 & 0.011 & 0.59 & 0.41 & 0.92 \\
\hline $17: 1$ cis -10 & 0.16 & 0.15 & 0.15 & 0.008 & 0.68 & 0.45 & 0.45 \\
\hline 18:0 iso & 0.04 & 0.04 & 0.03 & 0.005 & 0.96 & 0.94 & 0.83 \\
\hline $18: 0$ & 10.30 & 10.62 & 10.46 & 0.559 & 0.62 & 0.35 & 0.63 \\
\hline trans-10 18:1 & 0.45 & 0.44 & 0.48 & 0.037 & 0.56 & 0.89 & 0.40 \\
\hline trans-11 18:1 & 0.99 & 1.10 & 0.99 & 0.061 & 0.26 & 0.17 & 0.94 \\
\hline $18: 1$ trans total & 3.20 & 3.27 & 3.29 & 0.131 & 0.74 & 0.60 & 0.46 \\
\hline 18:1 cis total & 24.92 & 24.23 & 24.45 & 0.711 & 0.26 & 0.12 & 0.27 \\
\hline 18:1 total & 28.15 & 27.50 & 27.72 & 0.762 & 0.30 & 0.15 & 0.30 \\
\hline 18:2 cis-9,cis-12 & 1.99 & 1.90 & 1.92 & 0.052 & 0.48 & 0.28 & 0.39 \\
\hline CLA total & 0.61 & 0.63 & 0.58 & 0.032 & 0.16 & 0.44 & 0.20 \\
\hline $18: 3$ cis- $6,9,12$ & 0.04 & 0.04 & 0.04 & 0.002 & 0.27 & 0.17 & 0.16 \\
\hline $18: 3$ cis- $9,12,15$ & 0.31 & 0.28 & 0.29 & 0.017 & 0.44 & 0.23 & 0.40 \\
\hline $19: 0^{4}$ & 0.07 & 0.07 & 0.08 & 0.004 & 0.32 & 1.00 & 0.20 \\
\hline $19: 1^{5}$ & 0.09 & 0.09 & 0.09 & 0.003 & 0.15 & 0.84 & 0.08 \\
\hline 20:0 & 0.15 & 0.15 & 0.15 & 0.006 & 0.95 & 0.75 & 0.88 \\
\hline $20: 1$ cis -9 & 0.11 & 0.11 & 0.11 & 0.005 & 0.90 & 0.74 & 0.93 \\
\hline $20: 2 \mathrm{n}-6$ & 0.03 & 0.03 & 0.03 & 0.007 & 0.37 & 0.23 & 0.23 \\
\hline $20: 5 n-3$ & 0.03 & 0.03 & 0.03 & 0.001 & 0.41 & 0.26 & 1.00 \\
\hline $22: 0$ & 0.06 & 0.06 & 0.06 & 0.005 & 0.66 & 0.83 & 0.40 \\
\hline $22: 5 n-3$ & 0.06 & 0.06 & 0.05 & 0.006 & 0.83 & 0.84 & 0.71 \\
\hline $24: 0$ & 0.04 & 0.03 & 0.03 & 0.006 & 0.53 & 0.27 & 0.57 \\
\hline$\Sigma \mathrm{SFA}$ & 63.65 & 64.26 & 63.78 & 0.751 & 0.52 & 0.29 & 0.81 \\
\hline$\Sigma$ MUFA & 31.08 & 30.46 & 30.84 & 0.734 & 0.42 & 0.21 & 0.60 \\
\hline$\Sigma$ PUFA & 3.97 & 3.86 & 3.90 & 0.080 & 0.65 & 0.38 & 0.56 \\
\hline Number of animals & 6 & 6 & 6 & & & & \\
\hline
\end{tabular}

${ }^{1}$ Probability for the effect of treatment (Trt), the difference between control and $500 \mathrm{mg} / \mathrm{d}$ means $(0$ vs. 500$)$, or the difference between control and $2,500 \mathrm{mg} / \mathrm{d}$ means (0 vs. 2,500).

${ }^{2}$ Co-elutes with 17:0 anteiso.

${ }^{3}$ Co-elutes with 17:0 iso.

${ }^{4}$ Co-elutes with cis-15 18:1.

${ }^{5}$ Co-elutes with trans-12,cis-15 18:2.

decrease in ME, we observed an equivalent numerical decrease in tissue energy balance $(P<0.16)$ for the higher dose. This, combined with a slight reduction in milk energy excretion, led to a reduction $(P<0.05)$ in total energy balance (milk plus tissue) when the highest dose of $3 \mathrm{NP}$ was provided. 
Table 4. Effects of 3-nitrooxypropanol on intake and digestion of diet DM, OM, NDF, and ADF by lactating dairy cows

\begin{tabular}{|c|c|c|c|c|c|c|c|}
\hline \multirow[b]{2}{*}{ Item } & \multicolumn{3}{|c|}{ Dose, mg/d } & \multirow[b]{2}{*}{ SEM } & \multicolumn{3}{|c|}{$P<1$} \\
\hline & 0 & 500 & 2,500 & & Trt & 0 vs. 500 & 0 vs. 2,500 \\
\hline DMI, kg/d & 18.9 & 18.8 & 18.5 & 0.74 & 0.74 & 0.83 & 0.46 \\
\hline Fecal DM, kg/d & 4.67 & 5.03 & 5.01 & 0.336 & 0.13 & 0.07 & 0.09 \\
\hline DM digested, $\mathrm{kg} / \mathrm{d}$ & 14.24 & 13.79 & 13.48 & 0.516 & 0.34 & 0.38 & 0.16 \\
\hline DM digested, $\mathrm{kg} / \mathrm{kg}$ & 0.753 & 0.736 & 0.726 & 0.009 & 0.17 & 0.22 & 0.08 \\
\hline OM intake, $\mathrm{kg} / \mathrm{d}$ & 17.5 & 17.4 & 17.1 & 0.68 & 0.74 & 0.88 & 0.48 \\
\hline Fecal OM, kg/d & 4.08 & 4.26 & 4.18 & 0.22 & 0.58 & 0.32 & 0.58 \\
\hline OM digested, kg/d & 13.5 & 13.1 & 12.8 & 0.49 & 0.36 & 0.40 & 0.16 \\
\hline $\mathrm{OM}$ digested, $\mathrm{kg} / \mathrm{kg}$ & 0.774 & 0.757 & 0.747 & 0.009 & 0.14 & 0.18 & 0.06 \\
\hline NDF intake, $\mathrm{kg} / \mathrm{d}$ & 7.66 & 7.27 & 7.38 & 0.23 & 0.18 & 0.08 & 0.19 \\
\hline Fecal NDF, kg/d & 2.66 & 2.89 & 2.94 & 0.17 & 0.10 & 0.09 & 0.05 \\
\hline NDF digested, kg/d & 4.89 & 4.42 & 4.50 & 0.19 & 0.19 & 0.10 & 0.15 \\
\hline NDF digested, $\mathrm{kg} / \mathrm{kg}$ & 0.644 & 0.590 & 0.618 & 0.015 & 0.25 & 0.14 & 0.37 \\
\hline $\mathrm{ADF}$ intake, $\mathrm{kg} / \mathrm{d}$ & 5.44 & 5.14 & 5.07 & 0.23 & 0.29 & 0.23 & 0.15 \\
\hline Fecal ADF, kg/d & 1.58 & 1.76 & 1.74 & 0.10 & 0.08 & 0.05 & 0.06 \\
\hline ADF digested, kg/d & 3.80 & 3.40 & 3.36 & 0.18 & 0.21 & 0.14 & 0.12 \\
\hline ADF digested, kg/kg & 0.703 & 0.658 & 0.659 & 0.016 & 0.12 & 0.08 & 0.08 \\
\hline Number of animals & 6 & 6 & 6 & & & & \\
\hline
\end{tabular}

${ }^{1}$ Probability for the effect of treatment (Trt), the difference between control and $500 \mathrm{mg} / \mathrm{d}$ means (0 vs. 500), or the difference between control and $2,500 \mathrm{mg} / \mathrm{d}$ means (0 vs. 2,500).

Table 5. Effects of 3-nitrooxypropanol on nitrogen balance of lactating dairy cows

\begin{tabular}{|c|c|c|c|c|c|c|c|}
\hline \multirow[b]{2}{*}{ Item } & \multicolumn{3}{|c|}{ Daily dose, mg/d } & \multirow[b]{2}{*}{ SEM } & \multicolumn{3}{|c|}{$P<1$} \\
\hline & 0 & 500 & 2,500 & & Trt & 0 vs. 500 & 0 vs. 2500 \\
\hline N Intake, $\mathrm{g} / \mathrm{d}$ & 549 & 557 & 532 & 25.8 & 0.76 & 0.81 & 0.64 \\
\hline Fecal N, g/d & 167 & 162 & 178 & 9.9 & 0.005 & 0.19 & 0.009 \\
\hline Digested N, g/d & 384 & 389 & 358 & 21.3 & 0.57 & 0.86 & 0.41 \\
\hline Digested N, g/g & 0.708 & 0.693 & 0.668 & 0.012 & 0.17 & 0.41 & 0.08 \\
\hline Urine N, g/d & 173 & 165 & 171 & 12.9 & 0.90 & 0.66 & 0.89 \\
\hline$\%$ of manure $\mathrm{N}$ & 51.7 & 48.2 & 49.4 & 1.9 & 0.53 & 0.28 & 0.47 \\
\hline Milk N, g/d & 146 & 142 & 135 & 14.1 & 0.49 & 0.64 & 0.25 \\
\hline$\%$ of intake $\mathrm{N}$ & 26.55 & 25.67 & 24.81 & 2.04 & 0.07 & 0.17 & 0.03 \\
\hline N Balance, $\mathrm{g} / \mathrm{d}$ & 84.8 & 77.5 & 36.9 & 21.2 & 0.18 & 0.77 & 0.10 \\
\hline
\end{tabular}

${ }^{1}$ Probability for the effect of treatment (Trt), the difference between control and $500 \mathrm{mg} / \mathrm{d}$ means (0 vs. 500), or the difference between control and $2,500 \mathrm{mg} / \mathrm{d}$ means ( 0 vs. 2,500$)$.

Table 6. Effects of 3-nitrooxypropanol on rumen $\mathrm{pH}$ and the time that rumen $\mathrm{pH}$ was below $\mathrm{pH} 5.7,6.0$, and 6.5 over the $48 \mathrm{~h}$ of continuous recording

\begin{tabular}{|c|c|c|c|c|c|c|c|}
\hline \multirow[b]{2}{*}{ Item } & \multicolumn{3}{|c|}{ Dose, $\mathrm{mg} / \mathrm{d}$} & \multirow[b]{2}{*}{ SEM } & \multicolumn{3}{|c|}{$P<<^{1}$} \\
\hline & 0 & 500 & 2,500 & & Trt & 0 vs. 500 & 0 vs. 2,500 \\
\hline Manual $\mathrm{pH}^{2}$ & 6.27 & 6.20 & 6.32 & 0.062 & 0.001 & 0.03 & 0.10 \\
\hline Mean pH logger ${ }^{3}$ & 6.27 & 6.20 & 6.32 & 0.073 & 0.35 & 0.40 & 0.53 \\
\hline Minimum $\mathrm{pH}$ & 5.70 & 5.59 & 5.86 & 0.071 & 0.009 & 0.06 & 0.02 \\
\hline Maximum $\mathrm{pH}$ & 7.00 & 7.02 & 7.01 & 0.090 & 0.99 & 0.87 & 0.93 \\
\hline $\mathrm{SD} \mathrm{pH}$ & 0.26 & 0.28 & 0.22 & 0.018 & 0.02 & 0.34 & 0.04 \\
\hline Time $\mathrm{pH}<5.7, \mathrm{~h}$ & 0.71 & 0.66 & 0.56 & 0.294 & 0.34 & 0.58 & 0.18 \\
\hline Time $\mathrm{pH}<6.0, \mathrm{~h}$ & 3.23 & 3.88 & 2.21 & 1.044 & 0.09 & 0.29 & 0.13 \\
\hline Time $\mathrm{pH}<6.5, \mathrm{~h}$ & 14.11 & 14.21 & 14.74 & 2.143 & 0.88 & 0.94 & 0.66 \\
\hline Number of animals & 6 & 6 & 6 & & & & \\
\hline
\end{tabular}

${ }^{1}$ Probability for the effect of treatment (Trt), the difference between control and $500 \mathrm{mg} / \mathrm{d}$ means (0 vs. 500), or the difference between control and $2,500 \mathrm{mg} / \mathrm{d}$ means ( 0 vs. 2,500$)$.

${ }^{2}$ Measurements of $\mathrm{pH}$ at specific times relative to morning and afternoon feeding (Figure 1).

${ }^{3}$ Average of measurements at 15 -min intervals over $48 \mathrm{~h}$. 


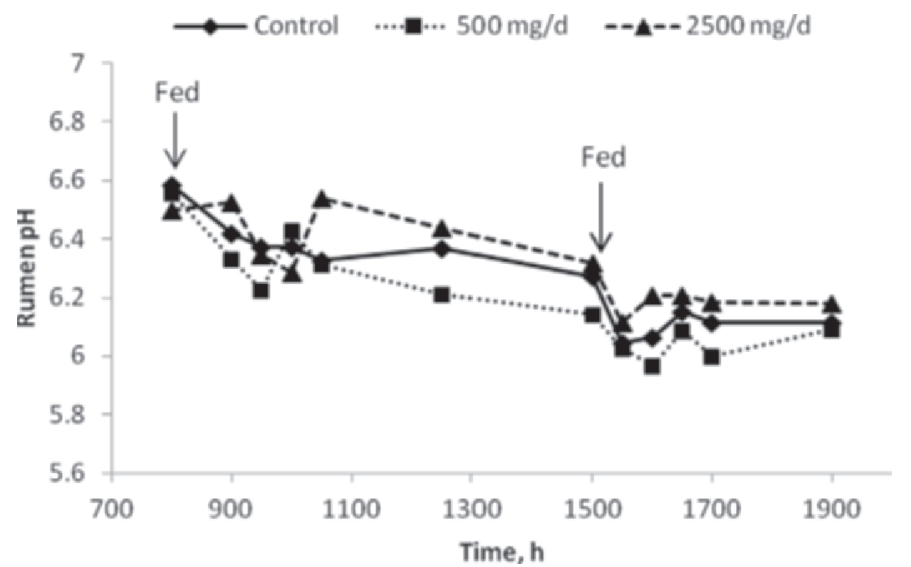

Figure 1. Rumen pH relative to a.m. and p.m. feeding and doses of 3-nitrooxypropanol measured using manual sampling of rumen fluid. Rumen $\mathrm{pH}$ was affected by time $(P<0.001)$ and treatment $(P<$ $0.001)$, but no time $\times$ treatment interaction $(P=0.82)$ was detected. The 3-nitrooxypropanol was introduced into the rumen through the rumen fistula in equal doses during rumen sampling just before feeding.

When parameters of energy metabolism were expressed as percentage of intake energy, significant reductions $(P<0.09$ or less $)$ in digestible energy recovery and methane energy loss occurred at both doses of the product (Table 9). Similarly, we detected reductions in the recovery of intake energy as $\mathrm{ME}(P<0.06)$ at the $2,500 \mathrm{mg} / \mathrm{d}$ dose. Milk energy $(P<0.06)$ as a percentage of intake energy was also lower when the $500 \mathrm{mg} / \mathrm{d}$ dose was provided. Finally, recovery of intake energy as

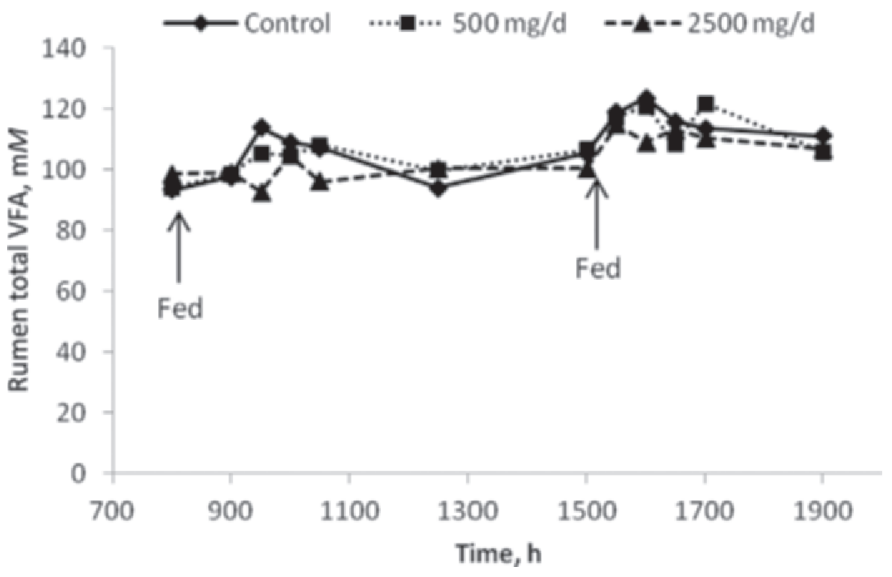

Figure 2. Rumen concentrations of total VFA relative to a.m. and p.m. feedings and doses of 3-nitrooxypropanol. The 3-nitrooxypropanol was introduced into the rumen through the rumen fistula during rumen sampling just before feeding.

total net energy balance was lower $(P<0.04)$ when the $2,500 \mathrm{mg} / \mathrm{d}$ dose was provided. This reflects combined changes in ME supply along with numerical changes in heat production, tissue energy retention, and milk energy excretion. When energy metabolism was expressed as a percentage of digested energy, the $2,500 \mathrm{mg} / \mathrm{d}$ dose increased heat production $(P<0.04)$ and decreased total energy balance $(P<0.06)$, but neither dose of $3 \mathrm{NP}$ affected the proportion of digestible energy lost as methane or recovered as ME (data not shown). This suggests that effects of $3 \mathrm{NP}$ on methane production

Table 7. Effects of 3-nitrooxypropanol on rumen VFA, ethanol, and ammonia concentrations before and after a.m. and p.m. feedings (meals) ${ }^{1}$

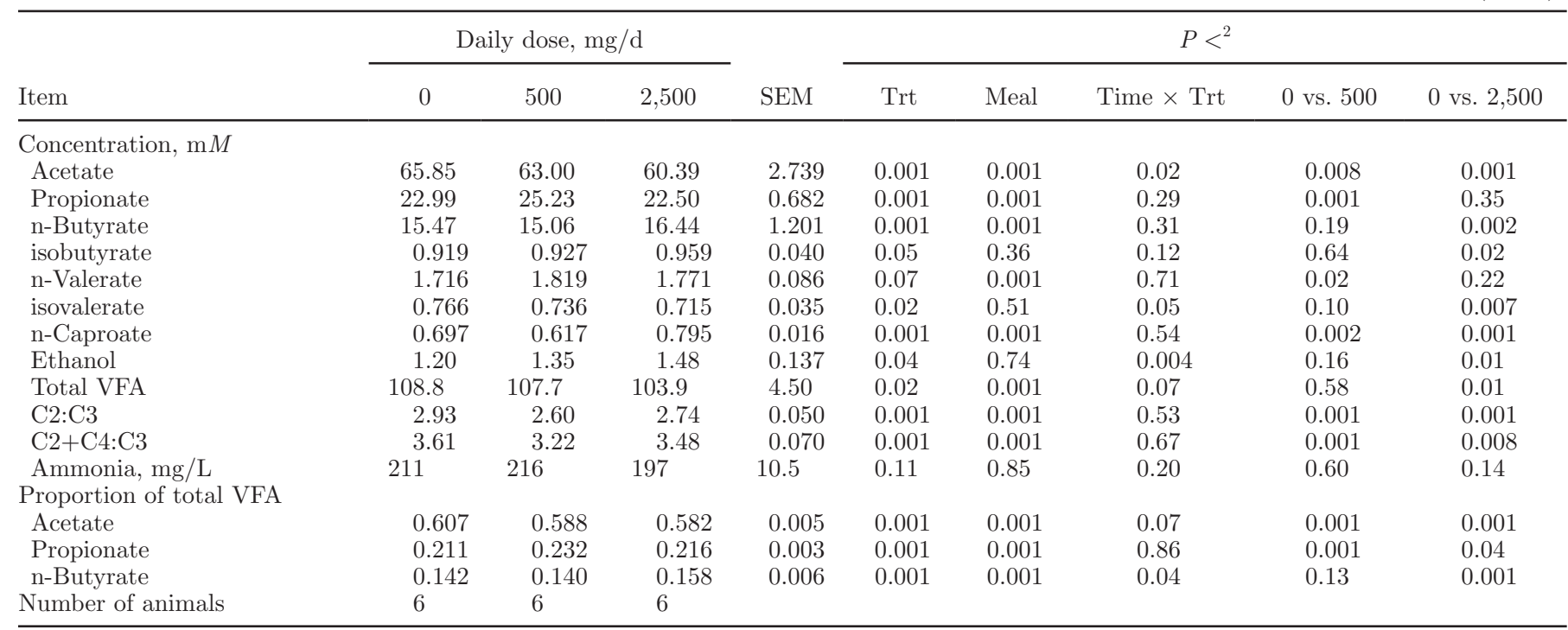

${ }^{1}$ Means of measurements $(\mathrm{n}=12)$ made at intervals before and after morning and afternoon meals.

${ }^{2}$ Probability for the effect of treatment (Trt), time, meal (a.m. or p.m. feeding), time by treatment interaction (time $\times$ Trt), the difference between control and $500 \mathrm{mg} / \mathrm{d}$ means (0 vs. 500$)$, or the difference between control and $2,500 \mathrm{mg} / \mathrm{d}$ means $(0$ vs. 2,500). Time was significant $[P$ $<0.001$ except acetate concentration $(P<0.07)]$ for all VFA concentrations and proportions presented. 


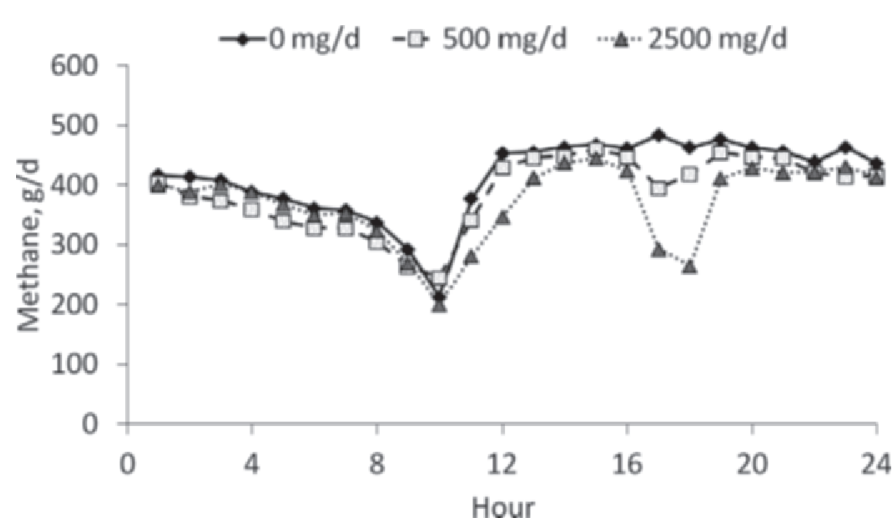

Figure 3. Hourly averages of methane production measured at 4-min intervals for lactating dairy cows receiving doses of 3-nitrooxypropanol into the rumen immediately before feeding at 0930 and $1530 \mathrm{~h}$.

were associated with, and in part due to, the reduction in dietary energy digestion observed.

\section{DISCUSSION}

\section{Effects on Methane Production}

As observed in sheep (Martínez-Fernández et al., 2014), 3NP dosed into the rumen of lactating dairy cows reduced methane production and methane yield (methane per unit of DMI). However, the magnitude of the effect of $3 \mathrm{NP}$ was marginally less in the present study (6.6 and $9.8 \%$ reductions for the low and high doses, respectively) than observed by Martínez-Fernández et al. (2014) in sheep (16\% for $100 \mathrm{mg} / \mathrm{d})$. It is unlikely that this difference in effect was due to a relative difference in the dose used, because on either a BW or a metabolic BW $\left(\mathrm{BW}^{0.75}\right)$ basis, the $2,500 \mathrm{mg} / \mathrm{d}$ dose in the present study $(3.7 \mathrm{mg} / \mathrm{kg}$ of $\mathrm{BW}$ or $18.9 \mathrm{mg} / \mathrm{kg}$ of $\mathrm{BW}^{0.75}$ ) was higher than the dose administered to sheep $\left(2.3 \mathrm{mg} / \mathrm{kg}\right.$ of BW or $\left.5.9 \mathrm{mg} / \mathrm{kg} \mathrm{BW}{ }^{0.75}\right)$. Although the mechanism of action would be different from that of
$3 \mathrm{NP}$, previous studies with organic dicarboxylic acids have found them to be effective at reducing methane production by sheep but not lactating dairy cows (e.g., McCourt et al., 2008; Foley et al., 2000). This may be due to differences between maintenance-fed sheep and lactating dairy cows in terms of their diets, rumen microbial ecology, or rumen dynamics, such as rumen outflow rate. These differences in rumen digesta and fluid kinetics may have altered the kinetics of 3NP disappearance and effective concentration in the rumen of the lactating cows compared with sheep. It was notable that, in the present study, a 5 -fold increase in the dose of the product did not have a 5 -fold greater effect on methane production, but the kinetics of the metabolism, absorption, and disappearance of the $3 \mathrm{NP}$ from the rumen would be influenced by the dosing method used.

Measurements of methane production over the course of daily measurements at 4-min intervals showed that the product, when dosed in the afternoon, had a pronounced but short-term inhibitory effect on methane production. This was particularly evident following administration of the $2,500 \mathrm{mg} / \mathrm{d}$ dose (Figure 3), when the lowest concentration of methane in chamber exhaust air was observed 1 to $2 \mathrm{~h}$ after the dose was given. Reasons for the acute nature of the effect observed following the afternoon dose are not certain. The animals were fed after receiving the dose, which provided more fermentable material for methane production, but this was also true following the morning dose. Meal patterns were not measured, but the size and spacing of the morning and afternoon meals differed. As the compound is water soluble, it is likely that the material was washing out of the rumen with liquid outflow. In addition, the 3NP may have been absorbed from the rumen or metabolized by the rumen microbes. The archaea, or specific archaea, may have adapted to the inhibitory effects of $3 \mathrm{NP}$ but, on average, methane production was lower throughout daily measurements

Table 8. Effects of 3-nitrooxypropanol on methane production by lactating dairy cows

\begin{tabular}{|c|c|c|c|c|c|c|c|}
\hline \multirow[b]{2}{*}{ Item } & \multicolumn{3}{|c|}{ Daily dose (mg/d) } & \multirow[b]{2}{*}{ SEM } & \multicolumn{3}{|c|}{$P<<^{1}$} \\
\hline & 0 & 500 & 2,500 & & Trt & 0 vs. 500 & 0 vs. 2,500 \\
\hline DMI, kg/d & 18.9 & 18.8 & 18.5 & 0.7 & 0.74 & 0.83 & 0.46 \\
\hline $\mathrm{CH}_{4}, \mathrm{~L} / \mathrm{d}$ & 594 & 555 & 536 & 15.3 & 0.01 & 0.03 & 0.005 \\
\hline $\mathrm{CH}_{4}, \mathrm{~g} / \mathrm{d}$ & 425 & 398 & 384 & 11.0 & 0.01 & 0.03 & 0.005 \\
\hline $\mathrm{CH}_{4}, \mathrm{MJ} / \mathrm{d}$ & 23.5 & 22.0 & 21.2 & 0.6 & 0.01 & 0.03 & 0.005 \\
\hline $\mathrm{CH}_{4}, \mathrm{~L} / \mathrm{kg}$ of $\mathrm{DMI}$ & 31.3 & 29.9 & 29.2 & 1.2 & 0.01 & 0.02 & 0.004 \\
\hline $\mathrm{CH}_{4}, \mathrm{~L} / \mathrm{kg}$ of milk & 23.1 & 23.1 & 23.8 & 3.5 & 0.58 & 0.98 & 0.38 \\
\hline $\mathrm{CH}_{4}, \mathrm{MJ} / \mathrm{MJ}$ of milk & 0.306 & 0.302 & 0.298 & 0.040 & 0.32 & 0.50 & 0.14 \\
\hline Number of animals & 6 & 6 & 6 & & & & \\
\hline
\end{tabular}

${ }^{1}$ Probability for the effect of treatment (Trt), the difference between control and $500 \mathrm{mg} / \mathrm{d}$ means (0 vs. 500), or the difference between control and $2,500 \mathrm{mg} / \mathrm{d}$ means ( 0 vs. 2,500$)$. 
REYNOLDS ET AL.

Table 9. Effects of 3-nitrooxypropanol on energy metabolism of lactating dairy cows

\begin{tabular}{|c|c|c|c|c|c|c|c|}
\hline \multirow[b]{2}{*}{ Item } & \multicolumn{3}{|c|}{ Daily dose, mg/d } & \multirow[b]{2}{*}{ SEM } & \multicolumn{3}{|c|}{$P<1$} \\
\hline & 0 & 500 & 2,500 & & Trt & 0 vs. 500 & 0 vs. 2,500 \\
\hline \multicolumn{8}{|l|}{$\begin{array}{l}\text { Components of energy balance, } \\
\mathrm{MJ} / \mathrm{d}\end{array}$} \\
\hline Intake & 349 & 347 & 340 & 14.2 & 0.75 & 0.85 & 0.48 \\
\hline Fecal & 86 & 89 & 87 & 5.0 & 0.66 & 0.40 & 0.80 \\
\hline Digested & 270 & 257 & 248 & 10.2 & 0.14 & 0.22 & 0.06 \\
\hline Urine & 8.7 & 8.0 & 8.4 & 0.7 & 0.63 & 0.35 & 0.70 \\
\hline Methane & 23.5 & 22.0 & 21.2 & 0.6 & 0.01 & 0.03 & 0.005 \\
\hline Metabolizable, MJ/d & 238 & 227 & 218 & 9.5 & 0.19 & 0.28 & 0.08 \\
\hline Metabolizable, MJ/kg of DMI & 12.48 & 11.98 & 11.96 & 0.18 & 0.16 & 0.11 & 0.09 \\
\hline Heat & 136 & 135 & 138 & 2.4 & 0.54 & 0.60 & 0.56 \\
\hline Milk & 85.0 & 81.3 & 79.5 & 7.9 & 0.48 & 0.43 & 0.26 \\
\hline Tissue & 20.0 & 7.4 & 0.2 & 8.8 & 0.34 & 0.35 & 0.16 \\
\hline Balance & 102 & 91 & 80 & 10.3 & 0.13 & 0.28 & 0.05 \\
\hline \multicolumn{8}{|l|}{ Percentage of intake energy } \\
\hline Digested & 76.4 & 74.1 & 73.7 & 0.8 & 0.06 & 0.06 & 0.03 \\
\hline Methane & 6.7 & 6.4 & 6.3 & 0.2 & 0.06 & 0.09 & 0.02 \\
\hline Urine & 2.5 & 2.3 & 2.5 & 0.1 & 0.63 & 0.50 & 0.82 \\
\hline Metabolizable & 67.3 & 65.4 & 64.8 & 0.8 & 0.13 & 0.12 & 0.06 \\
\hline Heat & 39.3 & 39.5 & 40.7 & 1.9 & 0.50 & 0.90 & 0.29 \\
\hline Milk & 24.0 & 23.1 & 23.6 & 1.6 & 0.14 & 0.06 & 0.27 \\
\hline Tissue & 5.4 & 2.0 & 0.0 & 2.5 & 0.36 & 0.38 & 0.17 \\
\hline Balance & 28.4 & 26.2 & 23.5 & 2.0 & 0.10 & 0.29 & 0.04 \\
\hline Number of animals & 6 & 6 & 6 & & & & \\
\hline
\end{tabular}

${ }^{1}$ Probability for the effect of treatment (Trt), the difference between control and $500 \mathrm{mg} / \mathrm{d}$ means $(0 \mathrm{vs} .500)$, or the difference between control and $2,500 \mathrm{mg} / \mathrm{d}$ means ( 0 vs. 2,500$)$.

(Figure 3), which were made during wk 5 of treatments. In the present study, we chose to dose the product into the rumen because of uncertainty about the stability of the product. However, a more continuous supply of $3 \mathrm{NP}$ to the rumen via an infusion, a sustained-release bolus, or by mixing with feed would provide a more appropriate evaluation of effective dose for application of the product.

It is also notable that the dose of product given in the morning did not have the same pronounced effect on methane production as was observed in the afternoon, but the morning dose was given at the end of the day's feeding cycle, when fermentable substrate supply and methane production is typically lowest in dairy cows (e.g., Moe et al., 1973). After feeding, 3NP limited the postprandial increase in methane production compared with control cows (Figure 3). These observations suggest that dosing $3 \mathrm{NP}$ into the rumen has differential effects depending on when it is introduced into the rumen relative to feeding or other diurnal factors influencing rumen fermentation.

\section{Rumen $\mathrm{pH}$ and VFA Concentrations}

Rumen $\mathrm{pH}$ decreased over the course of measurements (Figure 1), as would be expected with successive feedings and increasing supply of fermentable dietary substrates to the rumen. Rumen $\mathrm{pH}$ was decreased by the $500 \mathrm{mg} / \mathrm{d}$ dose of $3 \mathrm{NP}$ but increased by the 2,500 $\mathrm{mg} / \mathrm{d}$ dose. The decrease in rumen $\mathrm{pH}$ observed with the low dose was associated with an increase in rumen concentrations of propionate and n-valerate. Production of these VFA uses $\mathrm{H}^{+}$and is typically associated with less methane production. These results suggest that the low dose of $3 \mathrm{NP}$ shifted $\mathrm{H}^{+}$ion utilization from methanogenesis to propionate synthesis, but the extent to which propionate synthesis accounted for $\mathrm{H}^{+}$ions not used for methane synthesis is not certain. Emission of $\mathrm{H}_{2}$ from respiration chambers was not measured in the present study, but in previous studies with lactating dairy cows and sheep, the inhibitory effect of nitrate on methane production was associated with an increase in $\mathrm{H}_{2}$ expiration (van Zijderveld et al., 2011). Similarly, inhibition of methanogenesis by hemiacetyl of chloral and starch increased $\mathrm{H}_{2}$ concentration of rumen gas in sheep (Trei et al., 1972), and a variety of natural and synthetic inhibitors of methanogenesis increased incubation liquid $\mathrm{H}^{+}$ion concentration in vitro (Soliva et al., 2011).

The increase in rumen $\mathrm{pH}$ for the high dose of $3 \mathrm{NP}$ was associated with a decrease in total VFA concentrations (Table 7) and less variation (lower standard deviation) in rumen $\mathrm{pH}$ (Table 6). This decrease in total VFA concentration with the higher dose was due to a decrease in acetate concentration and, to a lesser extent, a decrease in isovalerate concentration, 
as concentrations of n-butyrate, isobutyrate, and ncaproate were increased (Table 7). A decrease in rumen concentration of acetate was also observed with the low dose of $3 \mathrm{NP}$, but this was accompanied by an increase in rumen concentrations of propionate and n-valerate, such that total VFA concentrations were unaffected. As observed in sheep (Martínez-Fernández et al., submitted), acetate:propionate and acetate + nbutyrate:propionate ratios were reduced by both doses of $3 \mathrm{NP}$, but the reduction for the low dose was attributable to the increase in propionate concentration. In sheep, $100 \mathrm{mg} / \mathrm{d}$ of $3 \mathrm{NP}$ decreased rumen concentration of acetate and increased rumen concentration of propionate (Martínez-Fernández et al., submitted). The decrease in rumen concentrations of total VFA and increase in rumen $\mathrm{pH}$ when the $2,500 \mathrm{mg} / \mathrm{d}$ dose was given in the present study were associated with a decrease in the digestibility of diet $\mathrm{DM}, \mathrm{OM}, \mathrm{N}, \mathrm{ADF}$, and energy. In addition, the increase in rumen propionate concentration for the $500 \mathrm{mg} / \mathrm{d}$ dose was associated with a decrease in NDF digestion and ADF digestibility (Table 4). This suggests that the $500 \mathrm{mg} / \mathrm{d}$ dose of 3NP modified rumen fermentation toward less methane and more propionate, whereas the $2,500 \mathrm{mg} / \mathrm{d}$ dose had greater inhibitory effects on substrate fermentation in the rumen than the lower dose. These effects of $3 \mathrm{NP}$ could be due to effects of increased $\mathrm{H}^{+}$ion concentrations that reduced fiber fermentation, reduced total VFA concentration, and increased rumen $\mathrm{pH}$ at the higher dose, and likely increased $\mathrm{H}_{2}$ expiration. These effects may be attributable to the sensitivity of fibrolytic microorganisms, protozoa, and fungi to $\mathrm{H}^{+}$partial pressure (Newbold et al., 2005; Morgavi et al., 2010). It has been reported that NADH oxidation is inhibited by $\mathrm{H}^{+}$accumulation, resulting in increased synthesis of ethanol (Wolin et al., 1997), which was observed for the $2,500 \mathrm{mg} / \mathrm{d}$ dose in the present study. In addition to the utilization of $\mathrm{H}^{+}$ions (Morgavi et al., 2010), there may be other synergistic benefits of archaea for rumen fermentation and digestion that were inhibited by $3 \mathrm{NP}$.

Rumen ammonia concentrations were not affected by treatments, although a numerical reduction was observed with the $2,500 \mathrm{mg} / \mathrm{d}$ dose (Table $7 ; P=0.14$ ) and the postprandial increase in rumen ammonia concentration after the morning feeding was suppressed when the $2,500 \mathrm{mg} / \mathrm{d}$ dose was administered (data not shown). Finally, these changes in rumen concentrations of VFA and $\mathrm{pH}$ were not associated with changes in milk FA profile (Table 3). In other studies, decreases in methane production have been associated with significant changes in milk FA profile and it has been suggested that milk FA profile can be used to predict methane production (Chilliard et al., 2009; Dijkstra et al., 2011). However, in many cases, changes in meth- ane production in these studies were a result of lipid supplementation (e.g., Mohammed et al., 2011), which changed both milk FA profile and methane yield.

\section{Energy and Nitrogen Balance}

We observed no adverse effects of $3 \mathrm{NP}$ treatment. The cow that aborted twins at the start of her third period had received the $2,500 \mathrm{mg} / \mathrm{d}$ dose for $5 \mathrm{~d}$ when she aborted, but this could have been a coincidence as the other pregnant cows were not affected. Feed DMI and milk yield were higher in wk 4 than in wk 5 (Tables 2 and 4), which may be due to prolonged effects of inactivity or restraint in respiration chambers (Reynolds, 2000). It is often purported that decreases in methane production will provide more ME for productive purposes, such as milk energy production or tissue energy retention (Blaxter and Czerkawski, 1966). In sheep, feeding hemiactyl of chloral and starch reduced methane in rumen gas and increased average daily weight gain (Trei et al., 1972). Similarly, feeding a halogenated methane analog to lactating goats reduced methane production and increased milk yield (Abecia et al., 2012). However, reductions in methane production are not always accompanied by increases in energy balance (milk plus tissue energy) in lactating dairy cows, even when digestible energy and ME intake are not affected (van Zijderveld et al., 2011). In the present study, we observed no effect of $3 \mathrm{NP}$ on DMI but detected a numerical reduction in milk yield $(P=0.19$; Table 2$)$ when the higher dose of the product was fed, which was associated with the decrease in diet digestibility and ME supply discussed previously. Methane energy as a percentage of digested energy was not affected by $3 \mathrm{NP}$, confirming that effects of $3 \mathrm{NP}$ on methane production in the present study were accompanied by decreases in the extent of NDF or ADF digestion. In contrast, however, 3NP or ethyl-3 nitrooxypropionate had no effect on in situ degradability of alfalfa hay or oats in sheep (Martínez-Fernández et al., submitted).

\section{CONCLUSIONS}

As observed in sheep, 3NP introduced into the rumen reduced methane production of lactating dairy cows by 6.6 and $9.8 \%$ for the 500 and $2,500 \mathrm{mg} / \mathrm{d}$ doses, respectively. A 5 -fold increase in the dose of $3 \mathrm{NP}$ did not have a 5 -fold greater effect on methane production, and a potent but transitory inhibitory effect on methane production was observed for 1 to $2 \mathrm{~h}$ after dosing in the afternoon, which may have been due to the kinetics of the metabolism, absorption, and rumen outflow of the compound. This suggests that mixing with feed or a sustained-release bolus may be a more 
effective delivery method, depending on the stability of the product. Changes in rumen concentrations of VFA and $\mathrm{pH}$ suggest that the pattern of rumen fermentation was affected by both doses of the product but that rumen fermentation was inhibited by the higher dose. Total digestibility of feed DM, OM, fiber, and protein were reduced, particularly at the higher dose. These differences in digestion and the observed shifts in rumen VFA concentrations suggest an inhibition of rumen fermentation of fiber, which may have been a consequence of pulse-dosing the larger amount of 3NP into the rumen. The resulting decrease in digestible energy supply was not completely countered by the decrease in methane excretion, such that ME supply and ME concentration of the TMR fed were reduced for the higher dose. These observations indicate that 3NP has potential as a dietary inhibitor of methanogenesis, but further research is needed to determine the optimal dose and method of delivery for achieving a significant reduction in methane production without the reductions in diet digestion observed when the higher dose of the product was provided in the present study.

\section{ACKNOWLEDGMENTS}

This research was funded by DSM Nutritional Products AG (Kaiseraugst, Switzerland), who also provided the 3-nitrooxypropanol. We gratefully acknowledge staff at the Centre for Dairy Research of the University of Reading for the care and management of animals used and for technical assistance during the study.

\section{REFERENCES}

Abecia, L., P. Toral, A. Martín-García, G. Martínez, N. Tomkins, E. Molina-Alcaide, C. Newbold, and D. Yáñez-Ruiz. 2012. Effect of bromochloromethane on methane emission, rumen fermentation pattern, milk yield, and fatty acid profile in lactating dairy goats. J. Dairy Sci. 95:2027-2036.

Aikman, P. C., P. H. Henning, D. J. Humphries, and C. H. Horn. 2011. Rumen $\mathrm{pH}$ and fermentation characteristics in dairy cows supplemented with Megasphaera elsdenii NCIMB 41125 in early lactation. J. Dairy Sci. 94:2840-2849.

Beauchemin, K. A., M. Kreuzer, F. O'Mara, and T. A. McAllister. 2008. Nutritional management for enteric methane abatement: A review. Aust. J. Exp. Agric. 48:21-27.

Blaxter, K. L., and J. Czerkawski. 1966. Modifications of methane production of the sheep by supplementation of its diet. J. Sci. Food Agric. 17:417-421

Bozic, A. K., R. C. Anderson, G. E. Carstens, S. C. Ricke, T. R. Callaway, M. T. Yokoyama, J. K. Wang, and D. J. Nisbet. 2009. Effects of methane-inhibitors nitrate, nitroethane, lauric acid, Lauricidin, and the Hawaiian marine algae Chaetoceros on ruminal fermentation in vitro. Bioresour. Technol. 100:4017-4025.

Cammell, S. B., J. D. Sutton, D. E. Beever, D. J. Humphries, and R. H. Phipps. 2000. The effect of crop maturity on the nutritional value of maize silage for lactating dairy cows. 1. Energy and nitrogen utilization. Anim. Sci. 71:381-390.

Chilliard, Y., C. Martin, J. Rouel, and M. Doreau. 2009. Milk fatty acids in dairy cows fed whole crude linseed, extruded linseed, or linseed oil, and their relationship with methane output. J. Dairy Sci. 92:5199-5211.

Clapperton, J. L. 1974. The effect of trichloroacetamide, chloroform and linseed oil given into the rumen of sheep on some of the endproducts of rumen digestion. Br. J. Nutr. 32:155-161.

Dijkstra, J., S. M. van Zijderveld, J. A. Apajalahti, A. Bannink, W. J. J. Gerrits, J. R. Newbold, H. B. Perdok, and H. Berends. 2011. Relationships between methane production and milk fatty acid profiles in dairy cattle. Anim. Feed Sci. Technol. 166:590-595.

Duval, S., and M. Kindermann, inventors. 2012. Nitrooxy alkanoic acids and derivatives thereof in feed for reducing methane emission in ruminants, and/or to improve ruminant performance. S. Duval and M. Kindermann, assignees. US Patent 20,120,315,339.

Foley, P. A., D. A. Kenney, D. K. Lovett, J. J. Callan, T. M. Boland, and F. P. O'Mara. 2009. Effect of DL-malic acid supplementation on feed intake, methane emissions, and performance of lactating dairy cows at pasture. J. Dairy Sci. 92:3258-3264.

Gaines, W. L. 1928. The energy basis of measuring milk yield in dairy cows. Univ. Illinois Agric. Exp. Station Bull. 308. University of Illinois, Urbana, Illinois.

Goel, G., H. P. S. Makkar, and K. Becker. 2009. Inhibition of methanogens by bromochloromethane: Effects on microbial communities and rumen fermentation using batch and continuous fermentations. Br. J. Nutr. 101:1484-1492.

Halgren, T. A., R. B. Murphy, R. A. Friesner, H. S. Beard, L. L. Frye, W. T. Pollard, and J. L. Banks. 2004. Glide: A new approach for rapid, accurate docking and scoring. 2. Enrichment factors in database screening. J. Med. Chem. 47:1750-1759.

Kliem, K. E., C. K. Reynolds, D. J. Humphries, R. M. Kirkland, C. E. S. Barratt, K. M. Livingstone, and D. I. Givens. 2013. Incremental effect of a calcium salt of cis-monounsaturated fatty acids supplement on milk fatty acid composition in cows fed maize silage-based diets. J. Dairy Sci. 96:3211-3221

Martínez-Fernández, G., L. Abecia, A. Arco, G. Cantalapiedra-Híjar, A. I. Martín-García, E. Molina-Alcaide, M. Kindermann, S. Duval, and D. R. Yáñez-Ruiz. 2014. Effects of ethyl-3-nitrooxy propionate and 3-nitrooxypropanol on ruminal fermentation, microbial abundance, and methane emissions in sheep. J. Dairy Sci. 97:37903799. 10.3168/jds.2013-7398.

McAllister, T. A., and C. J. Newbold. 2008. Redirecting rumen fermentation to reduce methanogenesis. Aust. J. Exp. Agric. 48:7-13.

McCourt, A. R., T. Yan, S. Mayne, and J. Wallace. 2008. Effect of inclusion of encapsulated fumaric acid on methane production from grazing dairy cows. Page 64 in Proc. Br. Soc. Anim. Sci. Cambridge University Press, Cambridge, UK.

Mills, J. A. N., J. Dijkstra, A. Bannink, S. B. Cammell, E. Kebreab, and J. France. 2001. A mechanistic model of whole-tract digestion and methanogenesis in the lactating dairy cow: Model development, evaluation and application. J. Anim. Sci. 79:1584-1597.

Moe, P. W., H. F. Tyrrell, and N. W. Hooven. 1973. Physical form and energy value of corn grain. J. Dairy Sci. 56:1298-1304.

Mohammed, R., S. M. McGinn, and K. A. Beauchemin. 2011. Prediction of enteric methane output from milk fatty acid concentrations and rumen fermentation parameters in dairy cows fed sunflower, flax, or canola seeds. J. Dairy Sci. 94:6057-6068.

Morgavi, D. P., E. Forano, C. Martin, and C. J. Newbold. 2010. Microbial ecosystem and methanogenesis in ruminants. Animal 4:1024-1036.

Newbold, C. J., S. López, N. Nelson, J. Ouda, R. Wallace, and A. Moss. 2005. Propionate precursors and other metabolic intermediates as possible alternative electron acceptors to methanogenesis in ruminal fermentation in vitro. Br. J. Nutr. 94:27-35.

Reynolds, C. K. 2000. Measurements of energy metabolism. Pages 87-107 in Feeding Systems and Feed Evaluation Models. M. K. Theodorou and J. France, ed. CABI Publishing, Wallingford, UK.

Reynolds, C. K., S. B. Cammell, D. J. Humphries, D. E. Beever, J D. Sutton, and J. R. Newbold. 2001. Effects of post-rumen starch infusion on milk production and energy metabolism in dairy cows. J. Dairy Sci. 84:2250-2259

Soliva, C. R., S. L. Amelchanka, S. M. Duval, and M. Kreuzer. 2011. Ruminal methane inhibition potential of various pure compounds 
in comparison with garlic oil as determined with a rumen simulation technique (Rusitec). Br. J. Nutr. 106:114-122.

Sutton, J. D., R. H. Phipps, D. E. Beever, D. J. Humphries, G. F. Hartnell, J. L. Vicini, and D. L. Hard. 2003. Effect of method of application of a fibrolytic enzyme product on digestive processes and milk production in Holstein-Friesian cows. J. Dairy Sci. 86:546-556.

Tempelman, R. J. 2004. Experimental design and statistical methods for classical and bioequivalence hypothesis testing with an application to dairy nutrition studies. J. Anim. Sci. 82(E. Suppl.):E162E172.

Trei, J. E., G. C. Scott, and R. C. Parish. 1972. Influence of methane inhibition on energetic efficiency of lambs. J. Anim. Sci. 34:510515 . van Zijderveld, S. M. 2011. Dietary strategies to reduce methane emissions from ruminants. PhD Diss. Wageningen University, Wageningen, the Netherlands.

van Zijderveld, S. M., W. J. J. Gerrits, J. Dijkstra, J. R. Newbold, R. B. A. Hulshof, and H. B. Perdok. 2011. Persistency of methane mitigation by dietary nitrate supplementation in dairy cows. J. Dairy Sci. 94:4028-4038.

Wolin, M. J., T. L. Miller, and C. S. Stewart. 1997. Microbe-microbe interactions. Pages 467-491 in The Rumen Microbial Ecosystem. 2nd ed. P. N. Hobson and C. S. Stewart, ed. Blackie Academic \& Professional, London, UK. 